\title{
Does Welfare Provision Promote Democratic State Legitimacy? Evidence from Brazil's Bolsa Familia Program
}

\author{
Mattherw L. Layton \\ Maureen M. Donaghy \\ Lúcio R. Rennó
}

\section{ABSTRACT}

Conditional cash transfer programs may boost the electoral fortunes of incumbents among beneficiary groups, but do they also influence recipient attitudes toward state legitimacy? This article examines the relationship between Brazil's Bolsa Família program and recipients' sense of the Brazilian state's political legitimacy, from 2007 to 2014. Using AmericasBarometer data and propensity score matching, this study provides evidence that targeted cash benefits correlate with citizens' views of the state, but that this relationship is limited to increasing trust in core state institutions, local government, and incumbent political actors. Diffuse dimensions of regime legitimacy, including recipients' sense of political community, support for regime principles, and retrospective perceptions of national economic performance, are largely unaffected by the receipt of targeted benefits. Over time, the evidence also suggests that the impact of program receipt on these measures of support remains largely unchanged.

onditional cash transfer (CCT) programs are now among the most politically salient public policies in the Latin American region. The literature assessing the effects of CCT programs on regional politics has particularly focused on their impact on elections. ${ }^{1}$ Several scholars argue that incumbents accrue electoral benefits from such programs as the direct result of sensible, programmatic policymaking (e.g., Hunter and Sugiyama 2014; Zucco 2013). Other observers, however, claim that the popularity of these programs may reflect induced dependence and the political capture of beneficiaries (e.g., Hall 2008). Yet others argue that the net electoral impact for incumbents is negative, as nonrecipients turn away from incumbents (Corrêa and Cheibub 2016), or that there is no electoral impact (Bohn 2011).

Matthew L. Layton is an assistant professor of political science at Ohio University. laytonm@ohio.edu. Maureen M. Donaghy is an assistant professor of political science at Rutgers University. maureen.donaghy@rutgers.edu. Lúcio R. Rennó is an associate professor of political science at the Universidade de Brasília. luciorenno@unb.br 
Each of these arguments has quite different implications for normative understandings of CCT programs as mechanisms for political inclusion and the empowerment of the poor. Given past manipulations of social assistance programs for political ends in the Latin American region, where populist leaders captured the political support of poor voters through selective benefits (e.g., Penfold-Becerra 2007; Schady 2000), it is important to assess the political effects of this new generation of social programs on the region's citizens.

This article argues that measuring strictly electoral consequences for incumbent governments is only one means to study how social assistance shapes beneficiaries' connection to their political system. As others have also found, an important alternative is to assess the impact of social programs on beneficiaries' perceptions of the integrity and legitimacy of the regime, key political institutions, and the state itself (Grimes and Wängnerud 2010; Hunter and Sugiyama 2014; Meneguello 2010). We claim that this alternate analysis is fundamentally different from studying effects on incumbent vote share and provides the opportunity to test the populist motivations behind the implementation of CCT programs.

The existing literature defines a populist leader as an individual who, among other characteristics, rejects institutionalized forms of authority that challenge their central, personalized vision for the state and uses targeted benefit programs to bolster their legitimacy and authority among the poor (Kitschelt et al. 2010, 329, 33536; Weyland 2012, 209-17). Traditional political parties, branches of the government controlled by opposition groups, and liberal democratic values, such as fair competition for power, popular participation in the political process, and protections for diverse and minority voices, are potentially put at risk by such leaders and their followers. Accordingly, this study tests whether the receipt of CCT benefits has a significant relationship with broader perceptions of the legitimacy of state institutions and democratic values. Programs that build support for the executive at the expense of other state institutions and democratic values may bolster antidemocratic, populist political processes, while programs that build support for the executive and the democratic regime more broadly may promote democratic stability.

This article analyzes the case of Brazil's Bolsa Família program (BFP). This program, adopted in 2004, provides monthly cash transfers to more than 13 million Brazilian families living in extreme poverty, on the condition that they make sure that their school-age children attend classes and receive stipulated vaccines, among other criteria. It is now the largest CCT program in Latin America and directly benefits about 25 percent of all Brazilians (Cecchini and Madariaga 2011). On average, the value of the cash benefit is sufficient to supplement household income for impoverished families, but is nonetheless a fraction of the official monthly minimum salary.

To receive Bolsa Família, potential beneficiaries meet with municipal officials to enroll in a centralized registry system. Eligible families are then automatically selected into the program according to priority criteria based on per capita household income thresholds and budgetary availability. Municipalities also monitor compliance with program requirements. So long as beneficiaries meet program eligibility criteria, the duration of benefits has no limitations. 
Bolsa Família provides a key opportunity to study the effects of CCT programs on state legitimacy and democratic regime values for several reasons. First, as the largest such program in the world, it has an intrinsic importance. In addition, this program, together with Mexico's, has served as a model and test case for many similar programs in the region and around the world, making it vital to understand the full range of outcomes associated with these policies.

Third, during the period we study (i.e., before the impeachment of President Dilma Rousseff in 2016), a single ruling political party (the Workers' Party, PT) held power continuously across the two administrations responsible for the implementation and maintenance of the program (Presidents Luiz Inácio Lula da Silva and Rousseff). This provides a crucial opportunity to study democratic state legitimacy in a climate that controls for political factors that might otherwise confound the results. ${ }^{2}$ Furthermore, on the basis of the previous literature about Brazil's program (e.g., Sugiyama and Hunter 2013), there are plausible claims, tied to its allegedly transparent implementation, that beneficiaries of this program would develop higher levels of political system support than their nonrecipient peers.

The study uses nationally representative survey data from the AmericasBarometer, collected by the Latin American Public Opinion Project (LAPOP), to test the core hypothesis; namely, that CCT recipients will have significantly different attitudes about state legitimacy than their nonrecipient peers. The AmericasBarometer data from Brazil include an indicator for Bolsa Família recipients in each of five rounds of surveys from 2007, 2008, 2010, 2012, and 2014, as well as a number of questions related to political legitimacy. These data thus provide the opportunity to measure both the average (pooled) effect of receiving benefits and temporal shifts in average recipient orientations toward the political system across survey years. We employ statistical propensity score matching to preprocess the survey data with the aim to more reliably assess the statistical significance of differences between CCT recipients and their nonrecipient peers.

We find that, on average, recipients of Brazil's Bolsa Família program show significantly higher levels of specific political support, not only for incumbent political actors, but also for the regime's core political institutions and local governments. By contrast, diffuse dimensions of regime legitimacy, including BFP recipients' sense of political community, support for regime principles, and perceptions of national economic performance, are unrelated to the receipt of these targeted benefits. These patterns change little over time. Accordingly, benefits from BFP primarily correlate with more specific indicators of political legitimacy rather than with diffuse support for the regime or democratic values. The article's conclusion discusses the implications of these findings. 


\section{POLITICAL System SUPPORT AND CCT PRograMs}

This article assesses how conditional cash transfer programs relate to recipients' sense of political legitimacy. We see this as a fundamentally different and broader question than whether recipients are more likely to support the current government in an election. By differentiating between proximate, electoral effects and broader, systemic impacts of social assistance, we draw on theories of political legitimacy, which, in their classical form, distinguish between two dimensions of attitudes: specific and diffuse system support (Easton 1965).

According to Easton's classic conceptualization of these dimensions of political legitimacy, specific support refers to approval based on "a quid pro quo for the fulfillment of demands"; by contrast, diffuse support constitutes "attachment to a political object for its own sake," independent (except in the long run) of system outputs (Easton 1965, 268, 274). The literature has subsequently moved toward a multidimensional conceptualization of political legitimacy and a more nuanced understanding of its sources and effects, yet these contributions continue to use Easton's continuum of more specific to more diffuse system support (e.g., Booth and Seligson 2009; Dalton 2004; Norris 1999).

The difference between specific and diffuse forms of political legitimacy is important for our argument. Citizens clearly differentiate between the proximate practices of government and more abstract beliefs about the regime (Norris 1999); hence, the distinct relationships must be theorized separately. While it is arguably straightforward to understand how conditional cash transfer programs can provide strong instrumental incentives for their recipients to offer specific support for the incumbent government, it is less clear whether and how they might shape diffuse support in the context of democracy.

In terms of the instrumental connection, for those in extreme poverty, even supplementary cash transfers like those provided by most CCT programs may constitute a significant boost to household incomes (Soares et al. 2010). Beneficiaries who wish to defend this benefit might consequently deliver reciprocal support for the incumbent. Yet CCT programs also aim, at least conceptually, to offer a more technocratic, less politicized form of social assistance than that seen in previous social programs (Fiszbein and Schady 2009). If consistently successful in these parallel objectives, CCT programs may provide increased recipient acceptance of all state institutions and diffuse support for a political regime, not just the incumbent executive.

Alternatively, scholars have argued that the express purpose of a state's provision of assistance benefits is to promote regime stability through the "regulation" or "disciplining" of the poor, independent of whether such policies support the wellbeing of their beneficiaries (e.g., Piven and Cloward 1971; Soss et al. 2011). Perhaps more crucially in the Latin American context, there are several examples of populist leaders who have used public assistance programs to consolidate their personal authority, often at the expense of the political autonomy of their supporters and in opposition to the prerogatives of other branches of government (Bruhn, 1996; 
Brusco et al. 2004; Calvo and Murillo 2004; Díaz-Cayeros 2008; Graham and Kane 1998; Magaloni et al. 2009; Penfold-Becerra 2007; Rocha-Menocal 2001; Schady 2000). While such efforts may also produce specific forms of legitimacy for the incumbent among seemingly "regulated" or "disciplined" assistance-receiving followers, we do not expect that they would bolster the broader legitimacy of any components of the regime that these followers perceive to be autonomous from the populist leader. Indeed, the most normatively concerning form of populism, at least for proponents of democracy, would arguably be the one in which populist followers reject diffuse democratic values as incompatible with their leader's objectives. Thus it is imperative to test whether CCT recipients have different orientations, in terms of both specific and diffuse support toward their political system, when compared to their nonrecipient peers.

To take this discussion one step further, if we are to view political legitimacy as a continuum with more specific factors on one end and more diffuse on the other, we should expect to see positive correlations between CCT beneficiary status and specific dimensions of system support when basic needs are met and beneficiaries enter traditional reciprocity-based relationships with the incumbent government (Finan and Schechter 2012). As state-sponsored policies that attempt to meet extreme need among vulnerable groups in the population, most CCT programs probably fulfill the basic requirements of a quid pro quo arrangement between recipients and the state. As noted above, much of the academic literature on the political effects of CCT programs gives us reason to believe that CCT programs promote specific political support for incumbents, but this is not a universally shared perspective and therefore requires further empirical testing.

By contrast, significant relative differences in diffuse system support between CCT beneficiaries and their nonrecipient peers may only emerge over time, perhaps even over generations. If so, it would be unlikely to observe significant differences between the groups in the relatively short time since program conception. In addition, diffuse values in support of democracy may be largely ingrained among citizens across Latin America (Booth and Seligson 2009, 204). ${ }^{3}$ If democracy has become consolidated as "the only game in town" (Linz and Stepan 1996), then it would be unlikely that any single policy could significantly change that status quo.

Nevertheless, Easton also suggests that diffuse orientations may occasionally change in the short term, given a shock of sufficient magnitude (Easton 1975, 445). In a related argument regarding regime change in Latin America, Mainwaring and Pérez-Liñán (2013, 56-61) note that what they call "normative regime preferences" might change for many reasons, including abrupt, traumatic experiences; routine organizational change; gradual learning through positive or negative experiences with the regime; and international diffusion of norms, at least for important political actors.

Arguably, these explanations may also apply to the attitudes of CCT recipients. Differences in system support in more diffuse dimensions, particularly those related to the broader regime and its core values, may emerge rather quickly for CCT recipients compared to their nonrecipient peers, given the sizable impact these programs have on individual well-being. That these programs typically offer benefits on a 
monthly or bimonthly basis over extensive periods of time may reinforce or magnify the effect on beneficiaries (Cecchini and Madariaga 2011). If CCT programs truly are more technocratic than political, then the direction of the effect on diffuse support may be quite different from that previously proposed under populist leadership. Indeed, even over a relatively short time, CCT recipients might plausibly come to perceive that access to benefits is not primarily contingent on partisan or populist objectives and therefore is not linked to a single party or individual but to the larger political processes and values that characterize the regime.

Additionally, in the context of a federal system like Brazil's, many beneficiaries might plausibly find that different levels of government, all of which share responsibility for the administration and implementation of the program (Fenwick 2009, 2016; Lindert et al. 2007), have political leadership from different partisan backgrounds, which could further promote perceptions of the program's nonpartisan nature. If any of these explanations hold, beneficiaries would arguably develop a higher sense of diffuse support for their political system than their nonrecipient peers, all else equal.

Therefore, we have reason to believe that specific support will be relatively high among CCT beneficiaries when compared to nonrecipients, but it is unclear whether they will likewise have higher levels of diffuse support for their political system. Based on this discussion, we test two alternative hypotheses regarding CCT beneficiaries and their observed levels of political legitimacy as compared to their nonrecipient peers.

H1a. Reciprocity-based legitimacy: CCT beneficiaries exhibit higher levels of specific system support but no significant differences from their nonrecipient peers on diffuse system support.

H1b. Regime-based legitimacy: CCT beneficiaries exhibit higher levels of both specific and diffuse system support when compared to their nonrecipient peers.

If there are differences between CCT recipients and their nonrecipient peers, as we hypothesize, we secondarily test whether any observed differences vary over time. One might expect that the impact of the CCT on recipient political attitudes and behaviors would be greater early in a program's implementation because it is a novelty promoted by the incumbent government, but that such effects would fade over time as beneficiaries become acclimated to it. Indeed, Peixoto and Rennó (2011) and Zucco (2013) present evidence that suggests that relative incumbent vote share has fallen among BFP recipients in Brazil. Alternatively, program beneficiaries might become dependent on their cash transfers, or the immediate effect of the program might periodically be renewed as new beneficiaries are added. Thus, any observable effects of the program on recipient attitudes and behaviors may persist.

We seek to test which of these two hypothetical learned responses best matches the empirical data over time: habituation or sensitization. ${ }^{4}$ Again, it is likely that these processes will play out independently and uniquely for specific and diffuse dimensions of legitimacy. It must be clear, however, that we are not studying indi- 
vidual-level change over time but evaluating whether the extended existence of a social program has implications for average perceptions within the beneficiary group at different moments in time. We argue that the learned response may be observed collectively, based on how cross-sections of the population respond to the maintenance, retraction, or expansion of a program over time. Accordingly, we test the following two alternative hypotheses:

H2a. Habituation response: Differences in levels of perceived state legitimacy between CCT recipients and their nonrecipient peers fade, or at least become less pronounced, over time.

H2b. Sensitization response: Differences in levels of perceived state legitimacy between CCT recipients and their nonrecipient peers persist over time.

\section{Data AND Methods}

Given our focus on social policies adopted in the Latin American context, we primarily look to Booth and Seligson (2009) to guide our analysis. We assess the relative levels of legitimacy between CCT beneficiaries and their nonrecipient peers on six core dimensions of political legitimacy, listed in order from the most diffuse to the most specific: sense of political community, support for core regime principles, evaluations of regime economic performance, support for regime institutions, support for local government, and support for political actors. ${ }^{5}$

Ideally, we would conduct a controlled randomized experiment to assess the causal effect of Bolsa Família on these attitudes. Several potential recipient households would be randomly assigned to "treatment" and "control" groups, for which inclusion in the Bolsa Família program would be the "treatment" and exclusion from the program would be the "control." After a fixed period, outcomes related to legitimacy would be measured. We could subsequently estimate the average treatment effect by testing the statistical significance of the difference in mean levels of attitudes related to legitimacy between beneficiaries and nonbeneficiaries.

In our case, however, the program is already in operation, which would make it difficult to construct an unbiased experiment along these lines. In addition, there are several practical challenges that impede such policy experiments in practice, including ethical concerns about withholding social interventions from populations that need assistance. Despite these concerns, some policymakers have been willing to conduct community-based randomization, particularly where there are budgetary barriers to full program implementation in early phases of a project (e.g., Levy 2006). Nevertheless, such aggregated randomization would potentially limit the inferences we would be able to make about the theoretical processes we have spelled out above.

We consequently employ observational methods to address our research question. To test the effect of Bolsa Família on the attitudes of its recipients, we draw on five rounds of the AmericasBarometer survey data in Brazil (2007, 2008, 2010, 2012, and 2014). ${ }^{6}$ Each round of these nationally representative surveys asks an identifying question to determine if the respondent or someone in their household receives Bolsa 
Família benefits. ${ }^{7}$ Because Bolsa Família is a means-tested program, it is distributed nonrandomly in the population. Therefore, we use the identifying question in each wave of the survey to develop matched samples of recipient and nonrecipient pairs using propensity score matching. This method allows us to take the self-identified recipients and locate a nonrecipient match who has a similar likelihood (or propensity) to receive the "treatment" of participation in the BFP but who has nevertheless remained outside the program. ${ }^{8}$ Through this process, we seek to approximate the conditions of a randomized control trial to better evaluate differences between BFP recipients and their peers than we could if we used standard regression techniques. ${ }^{9}$

We calculate separate propensity scores for respondents in each survey wave (in effect, treating each survey wave as a separate stratum for the purposes of our calculations) by regressing beneficiary status on a series of respondent-based indicators, which include gender, age, household size, having children enrolled in school, level of education completed, employment status, relative household asset-based wealth, urban or rural residence, and region of residence. ${ }^{10}$ Following Guo and Fraser (2010), we then match recipients and nonrecipients using nearest-neighbor, one-toone matching without replacement and with a caliper equal to one-quarter of the standard deviation of the propensity score to ensure that matches could not be made across large distances. ${ }^{11} \mathrm{We}$ pool the matched samples from each of the survey waves to analyze differences between BFP respondents and their nonrecipient peers (based on our indicator of "treatment"; i.e., participation in the BFP) across the waves and then include survey-year interactions in our models to analyze the results over time. ${ }^{12}$

Because the number of recipients interviewed varies in each round of the data and hence, so does the size of each year's matched sample, we attach wave-based proportional weights to respondents in each wave's matched sample, so that each survey year is given equal importance in the pooled analysis. These weights are applied equally to every matched sample respondent from the wave, so they do not affect covariate balance or otherwise distort estimates within the survey year; the weights merely adjust the relative importance of respondents across years in our pooled estimates.

This particularly helps to account for the inclusion of the 2010 survey in Brazil, which included an oversample of nearly 1,000 respondents above the typical 1,500 for most AmericasBarometer surveys. Without the additional weights, our larger matched sample from that year would have an unwarranted and oversized effect on our final pooled estimates. With the weight, respondents from 2010 are given equal importance to those from each of the other survey years, which ensures that any idiosyncratic patterns from the 2010 data would not unduly influence the findings.

We also include survey-year fixed effects in the analysis to account for additional idiosyncratic wave-specific characteristics, to ensure that no single matched sample drives the results of our pooled analysis. We report the results of the simple model, which includes the treatment indicator and the fixed-effect variables, followed by summarized results from models that show the evolution of the estimated treatment coefficient in each survey year by interacting the treatment indicator and the fixed-effect indicators. 


\section{DEPENDENT VARIABLES}

In terms of dependent variables, we use a combination of indicators of each of the six dimensions of political legitimacy identified by Booth and Seligson (2009). Although we attempt to follow their measurement model of political legitimacy as closely as possible, some changes in indicators are necessary, given the limited availability of certain items across waves of the AmericasBarometer. Here we discuss our measures for each dimension in order, from the most specific to the most diffuse. We provide additional details, including an enumeration of the differences between our indicators and those of Booth and Seligson (2009), in the appendix.

We begin with what is typically seen as the most specific of these three dimensions: support for political actors. Much of the scholarly work on the political effect of CCT programs has focused on the impact of these programs on more generic measures of specific incumbent support, such as perceived job performance or job approval, political trust, affective response toward key political actors, or vote choice, and as already noted, have largely, though not exclusively, shown that participation in CCT programs is predictive of such support. ${ }^{13}$ Here, following Booth and Seligson $(2009,49)$, we seek to capture the perceived efficacy of the incumbent government on key issues, including the provision of security, efforts to combat corruption, and management of the economy. ${ }^{14}$ We use a three-item additive index from the following questions: "to what extent would you say that the current central government combats corruption in the government?" "to what extent would you say that the current central government improves citizen security?" and "to what extent would you say that the current central government manages the economy well?" These items are available from 2010 through 2014.

Second, as we have seen, local governments are crucial to the functioning of many CCT programs, including Brazil's Bolsa Família (Fenwick 2009, 2016; Fried 2012; Lindert et al. 2007). ${ }^{15}$ To measure support for local government, we use an item that asks respondents, "to what extent do you trust the municipal government?" Even if recipients primarily attribute responsibility for the program to the country's chief executive rather than to local officials, this measure allows us to assess CCT recipients' evaluations of their local government.

Third, we seek to measure support for core political institutions. As Norris $(1999,11)$ puts it, support for regime institutions refers to "attitudes towards governments, parliaments, the executive, the legal system and police, the state bureaucracy, political parties, and the military," and seeks to measure approval of the power or functions of a particular office, rather than approval of the officeholder. Beyond the executive, other major institutions of a democratic regime may serve as mechanisms of citizen representation between elections. Indeed, in many cases, these institutions (particularly legislatures) played or continue to play an important role in ensuring continued access to the benefits of CCT programs (Cecchini and Madariaga 2011).

Thus we seek to assess support for regime institutions among CCT beneficiaries to understand the breadth of their ties to the broader political system. To meas- 
ure support for core institutions, we use an eight-item additive index. The indicators we use ask respondents the following: "to what extent do you believe that the Brazilian justice system guarantees a fair trial? to what extent do you have respect for the Brazilian political institutions? to what extent do you believe that citizens' basic rights are well protected by the Brazilian political system? to what extent are you proud to live in the Brazilian political system? to what extent do you think that one should support the Brazilian political system? to what extent do you trust the judiciary? to what extent do you trust the National Congress?" and "to what extent do you trust the political parties?"

Moving to the more diffuse side of the legitimacy continuum, we first analyze an indicator of evaluations of the national economy. The literature on economic voting has shown how infrequently individuals make the cognitive linkage between their own pocketbook economic condition and overall sociotropic economic performance (Powers 2001). Moreover, the very process of inclusion in a social assistance program may well signal to recipients that all is not well with the overall economy, if they are unable to provide for their families without the benefit of government assistance (Rothstein 1998). Yet, as we have noted, the sudden infusion of cash into one's household through a CCT program may quickly alter one's outlook on broader systemic conditions. To measure regime economic performance, we use a question that asks respondents about their retrospective sociotropic economic evaluation: "do you think that the current economic situation is better, the same, or worse than twelve months ago?" We recode responses so that those who answer "better" or "the same" are coded 1 and those who respond "worse" are coded 0 . We model this indicator using logistic regression.

Next, we analyze an indicator of support for core regime principles. Given Brazil's status as a relatively stable democratic government during the period of our study, we focus on democratic regime principles related to support for participatory action on the part of citizens. We use an additive index of three items that ask respondents, "I want you to tell me to what extent you would approve or disapprove of the following actions: participation in legal demonstrations, participation in an organization or group to resolve community problems, and working in electoral campaigns for a political party or candidate." Previous research finds that individual evaluations of the outcomes of the political process are one of the strongest predictors of support for democracy (Evans and Whitefield 1995; Gibson et al. 1992; Lagos 1997, 2001; Morlino and Montero 1995; Wells and Krieckhaus 2006).

As clear beneficiaries of the political process, CCT recipients may therefore strongly support the underlying principles that make democracy possible (i.e., participation; Dahl 1971), even if they themselves are not participatory. Alternatively, as we have noted, it is possible that CCTs will make little difference in support for democratic values because these values already have near-universal acceptance across Latin America, or because recipients find it cognitively difficult to link the two concepts. We provide an empirical test of these competing expectations. ${ }^{16}$

We also analyze an indicator of respondents' sense of political community. A sense of "political community" is "usually understood to mean basic attachment to 
the nation beyond the present institutions of government and a general willingness to cooperate together politically" (Norris 1999, 10). CCT programs may shape how recipients think about their membership in the national community through the signals the programs send to recipients regarding the state's sense of their value (Hunter and Sugiyama 2014) or, even more directly, by stimulating the formal documentation of recipients as citizens by encouraging recipients to register births and civil status to ensure eligibility under the program (Hunter and Sugiyama 2011, 2017). To measure respondents' sense of political community, the most diffuse of all the dimensions, we analyze respondents' answer to the question, "to what extent are you proud to be a Brazilian?" This variable is available in all years except 2014.

\section{RESULTS}

Table 1 presents the results for our pooled matched samples. Our dependent variables are ordered from most diffuse to most specific, from left to right in the table. The first line of coefficients represents the estimated treatment effect for receiving the Bolsa Família benefit, with the standard errors reported in parentheses. ${ }^{17}$ In addition, we report estimated coefficients for the fixed survey-year effects. These coefficients should be interpreted in relation to the 2007 survey year unless otherwise noted. All variables are either dichotomous or are rescaled on a $0-1$ scale to facilitate interpretation of the coefficients. All coefficients are estimated using OLS regression, except for the models for economic perceptions, which use logistic regression.

Looking across the top line of results, it is evident that across all survey years, Bolsa Família recipients report significantly higher levels of support for core political institutions, trust in local government, and support for political actors than their matched nonrecipient peers. By contrast, recipients are not significantly more likely to have a sense of political community, support regime principles, or perceive better economic performance than nonrecipients. More specifically, on average, Bolsa Família recipients score 0.047 points higher (on a $0-1$ scale) than nonrecipients in terms of support for core institutions, 0.035 points higher than nonrecipients on trust in local government, and 0.060 points higher on support for political actors. Note that these are the three most specific dimensions of political legitimacy in the table.

As an additional note, the significant coefficients reported for the survey-year fixed effect indicators suggest that average political legitimacy changed significantly in Brazil between 2007 and 2014, at least among the population represented in the matched sample. In short, the results show that political legitimacy increased on many dimensions between 2007 and 2010 but has since decreased, especially in 2014, across every dimension. Importantly, the coefficients reported for the Bolsa Família indicator are estimated independently of these overall shifts in political legitimacy, which gives us greater confidence that the results we report are not simply the product of idiosyncratic effects of any given survey year. Overall, these results are consistent with hypothesis $1 \mathrm{a}$, the theoretical framework of reciprocitybased legitimacy, and lead us to reject hypothesis $1 \mathrm{~b}$, regime-based legitimacy. 
Table 1. Predictors of Political Legitimacy, Brazil, 2007-2014

(Pooled, Matched Sample Results)

\begin{tabular}{|c|c|c|c|c|c|c|}
\hline & $\begin{array}{c}\text { (1) } \\
\text { Political } \\
\text { Community }\end{array}$ & $\begin{array}{l}\text { (2) } \\
\text { Support for } \\
\text { Regime } \\
\text { Principles }\end{array}$ & $\begin{array}{c}(3) \\
\text { Regime } \\
\text { Economic } \\
\text { Performance }\end{array}$ & $\begin{array}{l}(4) \\
\text { Support for } \\
\text { Core } \\
\text { Institutions }\end{array}$ & $\begin{array}{c}(5) \\
\text { Trust in } \\
\text { Local } \\
\text { Government }\end{array}$ & $\begin{array}{c}\text { (6) } \\
\text { Support for } \\
\text { Political } \\
\text { Actors }^{c}\end{array}$ \\
\hline BFP Recipient & $\begin{array}{c}0.014 \\
(0.013)\end{array}$ & $\begin{array}{c}0.003 \\
(0.011)\end{array}$ & $\begin{array}{c}0.123 \\
(0.108)\end{array}$ & $\begin{array}{l}0.047^{* * *} \\
(0.011)\end{array}$ & $\begin{array}{r}0.035^{*} \\
(0.015)\end{array}$ & $\begin{array}{l}0.060^{* * *} \\
(0.013)\end{array}$ \\
\hline Survey year 2008 & $\begin{array}{c}0.052^{*} \\
(0.024)\end{array}$ & $\begin{array}{c}0.001 \\
(0.023)\end{array}$ & $\begin{array}{c}0.580^{*} \\
(0.243)\end{array}$ & $\begin{array}{c}0.003 \\
(0.028)\end{array}$ & $\begin{array}{c}-0.041 \\
(0.034)\end{array}$ & - \\
\hline Survey year 2010 & $\begin{array}{l}0.065^{* *} \\
(0.022)\end{array}$ & $\begin{array}{c}0.032 \\
(0.025)\end{array}$ & $\begin{array}{c}0.482^{*} \\
(0.210)\end{array}$ & $\begin{array}{l}0.046^{*} \\
(0.023)\end{array}$ & $\begin{array}{c}-0.034 \\
(0.030)\end{array}$ & - \\
\hline Survey year 2012 & $\begin{array}{c}0.023 \\
(0.026)\end{array}$ & $\begin{array}{c}-0.001 \\
(0.020)\end{array}$ & $\begin{array}{c}0.460^{*} \\
(0.214)\end{array}$ & $\begin{array}{c}0.014 \\
(0.026)\end{array}$ & $\begin{array}{c}-0.090^{* *} \\
(0.032)\end{array}$ & $\begin{array}{r}-0.044^{*} \\
(0.022)\end{array}$ \\
\hline Survey year 2014 & - & $\begin{array}{c}-0.043^{*} \\
(0.018)\end{array}$ & $\begin{array}{c}-0.484^{*} \\
(0.188)\end{array}$ & $\begin{array}{l}-0.076^{* *} \\
(0.024)\end{array}$ & $\begin{array}{l}-0.153^{* * *} \\
(0.031)\end{array}$ & $\begin{array}{c}-0.151^{* * *} \\
(0.021)\end{array}$ \\
\hline Constant & $\begin{array}{l}0.842^{* * *} \\
(0.021)\end{array}$ & $\begin{array}{l}0.674^{* * *} \\
(0.016)\end{array}$ & $\begin{array}{l}0.762^{* * *} \\
(0.171)\end{array}$ & $\begin{array}{l}0.410^{* * *} \\
(0.021)\end{array}$ & $\begin{array}{l}0.502^{* * *} \\
(0.027)\end{array}$ & $\begin{array}{l}0.476^{* * *} \\
(0.017)\end{array}$ \\
\hline $\begin{array}{l}\text { Number of } \\
\text { Observations }\end{array}$ & 2,073 & 2,617 & 2,644 & 2,326 & 2,663 & 1,970 \\
\hline $\begin{array}{l}\text { Wald Test } \\
\text { (F-statistic) }\end{array}$ & $3.178^{*}$ & $2.867^{*}$ & $13.457^{* * *}$ & $15.111^{* * *}$ & $9.290^{* * *}$ & $29.804^{* * *}$ \\
\hline
\end{tabular}

${ }^{*} \mathrm{p}<0.05 ;{ }^{* *} \mathrm{p}<0.01 ;{ }^{* * *} \mathrm{p}<0.001$

${ }^{\mathrm{N}}$ No data for 2014

${ }^{b}$ Estimates based on logit regression

'No data for 2007, 2008

Notes: The reference category for survey year is 2007 , except in model 6 , where the baseline survey year is 2010. All estimates are survey design effects-based and are calculated from a propensity score-matching preprocessed sample. All estimates are based on OLS regression, with the exception of model 3, which is based on logistic regression. Standard errors in parentheses.

Source: AmericasBarometer by LAPOP

Table 2 presents summarized results from our secondary models that include survey-year interactions with the Bolsa Família indicator. We report the joint significance and sign of the interaction coefficients for each available year; full results are included in the appendix. We include the pooled results for the BFP indicator from table 1 in the first line of table 2, for reference. Note that only one survey year shows a statistically significant result on any of the three most diffuse dimensions (i.e., 2012, for the Political Community model). By contrast, the findings for the most specific dimensions are largely consistent with the findings in table 1; they show that $\mathrm{BFP}$ recipients often report a higher level of political legitimacy than nonrecipients and that they do so in later waves as well as early waves of the survey data available to us. 
Table 2. Summary of Over-Time Analysis, Brazil, 2007-2014

(BFP*Survey-Year Interactive Models, Matched Sample Results)

\begin{tabular}{lcccccc}
\hline \hline & $\begin{array}{c}\text { Political } \\
\text { Community }\end{array}$ & $\begin{array}{c}\text { Support for } \\
\text { Regime } \\
\text { Principles }\end{array}$ & $\begin{array}{c}\text { Regime } \\
\text { Economic } \\
\text { Performance }\end{array}$ & $\begin{array}{c}\text { Support for } \\
\text { Core } \\
\text { Institutions }\end{array}$ & $\begin{array}{c}\text { Trust in } \\
\text { Local } \\
\text { Government }\end{array}$ & $\begin{array}{c}\text { Support for } \\
\text { Political } \\
\text { Actors }^{\mathrm{c}}\end{array}$ \\
\hline $\begin{array}{c}\text { Pooled Results } \\
\text { (table 1) }\end{array}$ & 0 & 0 & 0 & + & + & + \\
2007 & 0 & 0 & 0 & + & 0 & N/A \\
2008 & 0 & 0 & 0 & + & + & N/A \\
2010 & 0 & 0 & 0 & 0 & - & 0 \\
2012 & + & 0 & 0 & 0 & 0 & + \\
2014 & N/A & 0 & 0 & + & + & + \\
\hline \hline
\end{tabular}

(+) Significant, positive joint coefficient; (-) significant, negative joint coefficient; (0) joint coefficient not statistically significant; statistical significance threshold: $\mathrm{p}<0.05$

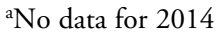

bEstimates based on logit regression

'No data for 2007, 2008

Notes: Results based on interactive cross-temporal models (see online appendix, table A3 for full results), showing statistical significance and sign of the joint marginal coefficient of BFP and survey-year indicators in each year. Results from Stata's margins command.

Source: AmericasBarometer by LAPOP

Still, we acknowledge that there are some anomalous patterns in these results; in particular, we report a statistically significant negative coefficient in 2010 for the Trust in Local Government model. Yet after further analysis, we are struck by an interesting pattern: BFP beneficiaries' attitudes about regime legitimacy are less variable than those of their nonrecipient peers in the sense that their average attitudes do not shift as radically from one period to the next (see table 3). Indeed, many of the unexpected results in table 2 are attributable to changes in the average level of legitimacy among nonbeneficiaries at least as much as to any changes among the BFP recipient groups. Taking this observation with the results from table 2, we argue that the sensitization hypothesis $(\mathrm{H} 2 \mathrm{~b})$ holds better than habituation $(\mathrm{H} 2 \mathrm{a})$. This is especially evident when we consider the average decline in political legitimacy observed after 2010 in table 1. Indeed, without the BFP recipients, declines in political legitimacy in Brazil could have been more dramatic.

We also acknowledge that the validity of the results and our ability to draw causal inferences from them depends on the core assumptions of our observational research design. In particular, our findings may fail to reflect the true relationships of interest, due to unobserved confounders that systematically affect both the propensity to report participation in Bolsa Família and reported perceptions of state legitimacy. For example, some individuals may have normative preferences related to the use of state welfare that correlate with their sense of the legitimacy of the state. Attitudes and behaviors might also be filtered through partisan preferences and motivations. We note, however, that in the years covered by our analysis, most 
Table 3. Wave-over-Wave Estimated Change in Predicted Values (vs. previous wave), Brazil, 2007-2014

(BFP*Survey-Year Interactive Models, Matched Sample Results)

\begin{tabular}{|c|c|c|c|c|c|c|}
\hline & & 2008 & 2010 & 2012 & 2014 & $\begin{array}{l}\text { Average } \\
\text { Absolute } \\
\text { Change }\end{array}$ \\
\hline \multirow[t]{2}{*}{$\begin{array}{l}\text { Political } \\
\text { Community }\end{array}$} & Recipient & $\begin{array}{c}0.008 \\
(0.036)\end{array}$ & $\begin{array}{c}0.031 \\
(0.023)\end{array}$ & $\begin{array}{c}-0.014 \\
(0.021)\end{array}$ & - & 0.018 \\
\hline & Nonrecipient & $\begin{array}{c}0.096 \\
(0.031)\end{array}$ & $\begin{array}{l}-0.005 \\
(0.018)\end{array}$ & $\begin{array}{c}-0.070 \\
(0.022)\end{array}$ & - & 0.057 \\
\hline \multirow[t]{2}{*}{$\begin{array}{l}\text { Support for } \\
\text { Regime Principles }\end{array}$} & Recipient & $\begin{array}{c}-0.017 \\
(0.026)\end{array}$ & $\begin{array}{c}0.020 \\
(0.028)\end{array}$ & $\begin{array}{c}-0.016 \\
(0.027)\end{array}$ & $\begin{array}{c}-0.047 \\
(0.023)\end{array}$ & 0.025 \\
\hline & Nonrecipient & $\begin{array}{c}0.018 \\
(0.035)\end{array}$ & $\begin{array}{c}0.042 \\
(0.036)\end{array}$ & $\begin{array}{c}-0.049 \\
(0.030)\end{array}$ & $\begin{array}{c}-0.037 \\
(0.024)\end{array}$ & 0.037 \\
\hline \multirow[t]{2}{*}{$\begin{array}{l}\text { Regime Economic } \\
\text { Performance }\end{array}$} & Recipient & $\begin{array}{c}0.101 \\
(0.054)\end{array}$ & $\begin{array}{c}-0.035 \\
(0.036)\end{array}$ & $\begin{array}{c}-0.021 \\
(0.037)\end{array}$ & $\begin{array}{c}-0.204 \\
(0.044)\end{array}$ & 0.090 \\
\hline & Nonrecipient & $\begin{array}{c}0.114 \\
(0.066)\end{array}$ & $\begin{array}{c}0.003 \\
(0.056)\end{array}$ & $\begin{array}{c}0.014 \\
(0.042)\end{array}$ & $\begin{array}{c}-0.194 \\
(0.044)\end{array}$ & 0.081 \\
\hline \multirow[t]{2}{*}{$\begin{array}{l}\text { Support for Core } \\
\text { Institutions }\end{array}$} & Recipient & $\begin{array}{c}-0.004 \\
(0.036)\end{array}$ & $\begin{array}{c}0.006 \\
(0.028)\end{array}$ & $\begin{array}{c}-0.019 \\
(0.024)\end{array}$ & $\begin{array}{c}-0.076 \\
(0.025)\end{array}$ & 0.026 \\
\hline & Nonrecipient & $\begin{array}{c}0.011 \\
(0.033)\end{array}$ & $\begin{array}{c}0.079 \\
(0.025)\end{array}$ & $\begin{array}{r}-0.044 \\
(0.022)\end{array}$ & $\begin{array}{c}-0.105 \\
(0.023)\end{array}$ & 0.060 \\
\hline \multirow[t]{2}{*}{$\begin{array}{l}\text { Trust in Local } \\
\text { Government }\end{array}$} & Recipient & $\begin{array}{c}-0.017 \\
(0.043)\end{array}$ & $\begin{array}{c}-0.066 \\
(0.035)\end{array}$ & $\begin{array}{c}-0.018 \\
(0.032)\end{array}$ & $\begin{array}{c}-0.047 \\
(0.033)\end{array}$ & 0.037 \\
\hline & Nonrecipient & $\begin{array}{l}-0.065 \\
(0.047)\end{array}$ & $\begin{array}{c}0.079 \\
(0.034)\end{array}$ & $\begin{array}{c}-0.092 \\
(0.029)\end{array}$ & $\begin{array}{c}-0.080 \\
(0.030)\end{array}$ & 0.079 \\
\hline \multirow[t]{2}{*}{$\begin{array}{l}\text { Support for } \\
\text { Political Actors }\end{array}$} & Recipient & - & - & $\begin{array}{c}-0.022 \\
(0.028)\end{array}$ & $\begin{array}{c}-0.110 \\
(0.031)\end{array}$ & 0.066 \\
\hline & Nonrecipient & - & - & $\begin{array}{c}-0.065 \\
(0.028)\end{array}$ & $\begin{array}{c}-0.103 \\
(0.025)\end{array}$ & 0.084 \\
\hline
\end{tabular}

Note: Reporting changes in predicted values compared to the previous survey year. Significant changes are in boldface $(\mathrm{p}<0.05)$. Standard errors in parentheses. Analysis conducted using the margins command in Stata.

Source: AmericasBarometer by LAPOP 
Brazilians reported relative consensus regarding the role of the state in providing for citizen welfare. Moreover, Brazil's atomized party system and low levels of partisan adherence would seemingly lead to different patterns of partisan identity politics than are found in other contexts. ${ }^{18}$

\section{DisCUSSION}

\section{AND CONCLUSIONS}

We see several points of interest in the findings we report. Consistent with Easton's classic theories on political legitimacy, the results demonstrate that Brazilian CCT recipients express greater specific support for their political system than their nonrecipient peers. Crucially, these differences extend beyond support for the incumbent president to other political institutions and levels of government. Although the differences we find appear to be small, in substantive terms these estimates are on a par with the average predicted electoral effect of CCT programs across the Latin American region (Layton and Smith 2015). Thus, we conclude that the immediate political consequences of CCTs are not limited to positive electoral results for incumbents.

By contrast, we find little support for the hypothesis that Bolsa Família is associated with diffuse dimensions of legitimacy. We cannot reject the null hypothesis regarding differences between $\mathrm{BFP}$ and non-BFP respondents' evaluations of the national economy or sense of political community. Moreover, there is no evidence that BFP recipients are more supportive of democratic regime principles. Taken together, these findings call into question the degree to which the program affects recipients' sense of social and political inclusion, at least at these more abstract levels. We conclude that either the time horizon is too short to demonstrate statistical significance for these diffuse measures of legitimacy or that social programs fail to change recipients' attitudes in this way.

It is perhaps encouraging, however, that Brazil's CCT recipients are not any less supportive of diffuse elements of the political regime than nonrecipients. Even if these recipients are merely indifferent about the importance of democracy relative to their nonrecipient peers, they have not turned against it, which we might otherwise expect if their attitudes were influenced by antidemocratic populist leaders. Future research is needed to demonstrate long-term trends among recipients and to draw definitive conclusions. Additionally, cross-national research may provide further illumination to better understand how contextual factors and alternative program features potentially shape perceptions of diffuse legitimacy among assistance recipients.

The results we report lead us to infer that Bolsa Família has promoted the emergence of a recipient class that demonstrates relative sensitivity to the benefits they receive. Recipients express significantly different attitudes about political legitimacy from their nonrecipient peers across several waves of the AmericasBarometer. Still, other factors, perhaps specific to the comparison group of nonrecipient peers, appear to intervene in any given year, either to diminish or increase the observed differences between recipients and nonrecipients. 
Given that the matched sample incorporates nonrecipients with similar propensities to receive the benefit but who, for whatever reason, fail to report participation in the program during the survey interview, we see the need for additional research about those individuals who fall just outside the purview of the program. Indeed, during previous fieldwork in Brazil, we encountered individuals who expressed considerable frustration at being left out of the program despite living in obvious conditions of poverty. Regardless of whether their income fell just above eligibility thresholds, their family circumstances made them a lower priority for inclusion in the program, or the government had reached its budgetary limits, these individuals arguably had a negative experience with government at least as powerful as the experiences of program participants. These exclusions warrant further examination.

Finally, BFP recipients' attitudes appear to be less variable than those of their nonrecipient peers. Although both BFP recipients and nonrecipients report declines in political legitimacy after 2010, the declines were more precipitous among nonrecipients than among recipients, on average. This perhaps befits a safety-net program. Of course, with an economic decline and turbulent national politics since 2014, Brazilians may now be less supportive of their political system than during the years covered by our analysis. Even so, our results suggest that the provision of Bolsa Família benefits may offset some of the discontent caused by these events, which, if borne out by empirical observation, would be a boon for political stability in hard times. Indeed, there is now an opportunity to test whether changes in partisan administration alter perceptions of political legitimacy for recipients.

In sum, this analysis illustrates that low-income citizens who participate in CCT programs hold more positive perceptions of the legitimacy of political institutions than their nonrecipient peers. To the extent that other CCT programs share the key characteristics of Brazil's Bolsa Família, and to the extent that this pattern reflects a causal relationship, these results suggest that CCT programs do not jeopardize the broader legitimacy of state institutions, nor do they exclusively concentrate support in the executive, as might be expected of a populist program. Still, our analysis cannot definitively claim that these programs are a short-term panacea to bolster support for democratic values. Long-term shifts in opinion among poor beneficiaries may eventually translate to more positive feelings toward the more diffuse dimensions of a country's democratic legitimacy, but our data have yet to reveal such a pattern. We therefore conclude that CCT beneficiaries exhibit attitudinal patterns that are consistent with reciprocity-driven perceptions of state legitimacy. Nevertheless, building state legitimacy in Brazil and in other countries with a significant need for targeted welfare programs remains a vital task. Even if CCT programs only produce reciprocal support for the state, as suggested by these results, they may yet help to stabilize political legitimacy in democracies during crises. 


\section{NOTES}

1. See, e.g., Baez et al. 2012; De la O 2013, 2015; Layton and Smith 2015; Licio et al. 2009; Linos 2013; Manacorda et al. 2011; Zucco 2008, 2013.

2. Freedom House gives Brazil a Freedom Rating of 2.0 between 2007 and 2014, the years included in our study (see freedomhouse.org). The Polity IV project gives Brazil a score of 8 (on its -10-to-10-point scale) for the same years (see systemicpeace.org).

3. According to data from the 2012 AmericasBarometer, 77.3 percent of all respondents in Latin America and the Caribbean agree with the statement, "Democracy is preferable to any other form of government" when asked to choose between that statement and the following two statements: "For people like me it doesn't matter whether a government is democratic or nondemocratic," or "Under some circumstances an authoritarian government may be preferable to a democratic one." According to the same data, 66.0 percent of Brazilian respondents agree with the prodemocratic statement.

4. We note that the data we use in our analysis do not allow us to test the effect of a change in the partisan identity of the administration.

5. We switch the order on two dimensions to follow Norris 1999. Regime economic performance and support for regime institutions have been inverted in their relative ranking on the diffuse-to-specific legitimacy continuum.

6. We thank the Latin American Public Opinion Project (LAPOP) and its major supporters (the U.S. Agency for International Development, the United Nations Development Program, the Inter-American Development Bank, and Vanderbilt University) for making the data available. All analyses were conducted using Stata v.14.

7. In the 2007 and 2008 rounds, the question was "Do you participate in the Bolsa Família program, from the federal government?"; in 2010 it was "In the last three years, have you or anyone who lives in your household been a beneficiary of the Bolsa Família program?"; finally, in 2012 and 2014 the question asked, "Now speaking specifically about the Bolsa Família program, are you or anyone in your household a beneficiary of this program?"

8. Although targeting has been reported to be quite good in the Bolsa Família program (Lindert et al. 2007), the Brazilian government has reported that the program's waiting list included more than 460,000 technically eligible families through January 2017 (see http://www.brasil.gov.br/cidadania-e-justica/2017/02/fila-de-espera-do-bolsa-familia-e-zeradaem-janeiro). Thus, in the period covered by our study, it is plausible that a significant number of comparable nonrecipients were included in the survey samples to match to self-reported recipients; it is also possible that some matches may include slightly wealthier nonrecipient respondents whose household incomes fall just above eligibility thresholds for the program. We argue that the difference between matched pairs under these conditions approximates a randomized experiment.

9. Matching only approximates a randomized experiment because it may improve balance on observed covariates when compared to standard regression techniques. Nevertheless, even if balance is achieved on observed covariates, there is no formal expectation that matching will balance unobserved covariates, meaning that there may still be bias in the estimates that threatens the validity of results (Guo and Fraser 2010, 280-81). Indeed, matching requires analysts to make a number of assumptions. Assignment to treatment is assumed to be independent of the outcomes of interest, and the observed outcome for a given individual cannot be dependent on the mechanism of assignment to treatment or the treatment status of other individuals (Guo and Fraser 2010, 30-36). We therefore must assume that participation in the Bolsa Família program precedes the formation of attitudes regarding political 
legitimacy and that any given respondent's attitudes are independent of the local rate of participation in BFP. We also assume that any effect that the BFP has on its recipients is constant across individuals. Collectively, these assumptions constitute the stable unit treatment value assumption (SUTVA). For additional analysis of the "common support region"; i.e., the range of values on the propensity score where observations from both the "treatment" and "control" groups overlap sufficiently to make reliable matches, see the online appendix.

10. See Córdova 2009 for details on use of the wealth index in LAPOP surveys.

11. We employ the Stata package psmatch2, developed by Leuven and Sianesi (2003). Matching improves covariate balance for all covariates in all years, with the exception of age and residents of the North region in the 2007 data. However, there is no statistically significant difference between treatment and control groups either pre- or postmatching on either of these two variables. Consequently, we remain confident that the matching procedure has produced comparable treatment and control groups in all cases. See the appendix for more details on covariate balance and for results of the propensity score models. Note that we have chosen to use propensity score matching, as opposed to a regression discontinuity design, because the income indicator in the AmericasBarometer surveys is not sensitive enough to produce sharp distinctions in household income at the relevant BFP cut points. What's more, respondents are much less likely to report income than the household asset indicators we use in our matching algorithm.

12. The pooled matched sample contains a total of 2,714 observations, evenly divided between Bolsa Família beneficiaries and nonbeneficiaries. Of these, 252 are from the 2007 data, 392 are from 2008, 950 are from 2010, 504 are from 2012, and 616 are from 2014. We also stress here that we do not intend to make arguments about individual-level change, as we do not have panel data. Instead we assess the effect of program receipt on a pooled sample and cross-sectional cuts of the Brazilian population, which allows us to evaluate changes in the average levels of political legitimacy for Bolsa Família program beneficiaries over time.

13. While Bohn (2011) does not find that Bolsa Família influenced the electoral preferences of low-income citizens between the 2002 and 2006 elections, a number of other scholars find positive associations between Lula's re-election in 2006 and support for the Bolsa Família program (Hunter and Power 2007; Licio et al. 2009; Marques and Mendes 2006, 2007; Moura 2007; Nicolau and Peixoto 2007; Soares and Terron 2008; Zucco 2008, 2013; Zucco and Power 2013). Furthermore, Licio et al. (2009) point out that being a beneficiary of the Bolsa Família program also increases positive evaluations of the incumbent government while it is in office.

14. Booth and Seligson (2009) use items that measure perceived efficacy in terms of fighting poverty, combating corruption, and promoting democratic principles. Although we would prefer to use the same indicators they use in their analysis, we have to balance that preference with our ability to measure our indicators of interest over time and across waves of the AmericasBarometer survey. Because not all items are found across all the years, we have chosen to use related items that are available across more waves. For purposes of comparison, we provide an analysis using the more traditional measure of presidential job approval as a dependent variable in the appendix.

15. Interestingly, Linos (2013) provides evidence that, at least in the context of Honduras, the CCT electoral benefit to incumbent executives accrues primarily to incumbent mayors, not the incumbent president.

16. We analyze alternate measures of support for democracy in our appendix.

17. We estimate the average treatment effect for the treated (ATT), comparing the average level of perceived political legitimacy between Bolsa Família beneficiaries and 
their nonrecipient peers, who nonetheless had similar predicted propensities to receive the benefit.

18. In separate analyses not reported here, we find that there is no significant difference between recipient and nonrecipient groups in our matched sample on average support for the statement, "the Brazilian state should implement strong policies to reduce income inequality between the rich and the poor." By contrast, we find a statistically significant difference on reported identification with the PT, with recipients more likely to identify as PT sympathizers, but at rather low levels (17.6 percent versus 14.2 percent for nonrecipients). However, given the nature of Brazil's party system and its low overall levels of party identification of any kind, we would argue that this parallels the patterns we report for specific system support. In short, we would hypothesize that BFP recipients are likely to adopt identification with the incumbent's party after entering the program, although we do not address this empirical question here. See the appendix for formal sensitivity analyses.

\section{REFERENCES}

Americas Barometer. 2007, 2008, 2010, 2012, 2014. Latin American Public Opinion Project (LAPOP). Nashville: Vanderbilt University. www.LapopSurveys.org

Baez, Javier E., Adriana Camacho, Emily Conover, and Román D. Zárate. 2012. Conditional Cash Transfers, Political Participation, and Voting Behavior. Policy Research Working Paper 6215. Washington, DC: World Bank.

Bohn, Simone R. 2011. Social Policy and Vote in Brazil: Bolsa Família and the Shifts in Lula's Electoral Base. Latin American Research Review 46, 1: 54-79.

Booth, John A., and Mitchell A. Seligson. 2009. The Legitimacy Puzzle in Latin America: Political Support and Democracy in Eight Nations. Cambridge: Cambridge University Press.

Bruhn, Kathleen. 1996. Social Spending and Political Support: The "Lessons" of the National Solidarity Program in Mexico. Comparative Politics 28, 2: 151-77.

Brusco, Valeria, Marcelo Nazareno, and Susan C. Stokes. 2004. Vote Buying in Argentina. Latin American Research Review 39, 2: 66-88.

Calvo, Ernesto, and María Victoria Murillo. 2004. Who Delivers? Partisan Clients in the Argentine Electoral Market. American Journal of Political Science 48, 4: 742-57.

Cecchini, Simone, and Aldo Madariaga. 2011. Conditional Cash Transfer Programmes: The Recent Experience in Latin America and the Caribbean. Santiago, Chile: ECLAC. http://repositorio.cepal.org/bitstream/handle/11362/27855/1/S1100263_en.pdf

Córdova, Abby. 2009. Methodological Note: Measuring Relative Wealth Using Household Asset Indicators. Insights Report I0806. Nashville: Latin American Public Opinion Project.

Corrêa, Diego Sanches, and José Antonio Cheibub. 2016. The Anti-Incumbent Effects of Conditional Cash Transfer Programs. Latin American Politics and Society 58, 1: 49-71.

Dahl, Robert. 1971. Polyarchy: Participation and Opposition. New Haven: Yale University Press.

Dalton, Russell J. 2004. Democratic Challenges, Democratic Choices: The Erosion of Political Support in Advanced Industrial Democracies. New York: Oxford University Press.

De la O, Ana L. 2013. Do Conditional Cash Transfers Affect Electoral Behavior? Evidence from a Randomized Experiment in Mexico. American Journal of Political Science 57, 1: $1-14$.

2015. Crafting Policies to End Poverty in Latin America: The Quiet Transformation. New York: Cambridge University Press. 
Díaz-Cayeros, Alberto. 2008. Electoral Risk and Redistributive Politics in Mexico and the United States. Studies in Comparative International Development 43, 2: 129-50.

Easton, David. 1965. A Systems Analysis of Political Life. New York: Wiley. 1975. A Re-Assessment of the Concept of Political Support. British Journal of Political Science 5, 4: 435-57.

Evans, Geoffrey, and Stephen Whitefield. 1995. The Politics and Economics of Democratic Commitment: Support for Democracy in Transition Societies. British Journal of Political Science 25, 4: 485-514.

Fenwick, Tracy B. 2009. Avoiding Governors: The Success of Bolsa Família. Latin American Research Review 44, 1: 102-31.

- 2016. Avoiding Governors: Federalism, Democracy, and Poverty Alleviation in Brazil and Argentina. Notre Dame: University of Notre Dame Press.

Finan, Frederico, and Laura Schechter. 2012. Vote-Buying and Reciprocity. Econometrica 80, 2: 863-81.

Fiszbein, Ariel, and Norbert Schady. 2009. Conditional Cash Transfers: Reducing Present and Future Poverty. Washington, DC: World Bank.

Fried, Brian. 2012. Distributive Politics and Conditional Cash Transfers: The Case of Brazil's Bolsa Família. World Development 40, 5: 1042-53.

Gibson, James L., Raymond M. Duch, and Kent L. Tedin. 1992. Democratic Values and the Transformation of the Soviet Union. Journal of Politics 54, 2: 329-71.

Graham, Carol, and Cheikh Kane. 1998. Opportunistic Government or Sustaining Reform? Electoral Trends and Public-Expenditure Patterns in Peru, 1990-1995. Latin American Research Review 33, 1: 67-104.

Grimes, Marcia, and Lena Wängnerud. 2010. Curbing Corruption Through Social Welfare Reform? The Effects of Mexico's Conditional Cash Transfer Program on Good Government. American Review of Public Administration 40, 6: 671-90.

Guo, Shenyang, and Mark W. Fraser. 2010. Propensity Score Analysis: Statistical Methods and Applications. Los Angeles: Sage.

Hall, Anthony. 2008. Brazil's Bolsa Família: A Double-Edged Sword? Development and Change 39, 5: 799-822.

Hunter, Wendy, and Natasha B. Sugiyama. 2011. Documenting Citizenship: Contemporary Efforts Toward Social Inclusion in Brazil. Paper presented at the American Political Science Association Annual Meeting, Seattle, September 1-4.

- 2014. Transforming Subjects into Citizens: Insights from Brazil's Bolsa Família. Perspectives on Politics 12, 4: 829-45.

. 2017. Making the Newest Citizens: Achieving Universal Birth Registration in Contemporary Brazil. Journal of Development Studies. Published online, June 28. http://dx.doi.org/10.1080/00220388.2017.1316378

Hunter, Wendy, and Timothy J. Power. 2007. Rewarding Lula: Executive Power, Social Policy, and the Brazilian Elections of 2006. Latin American Politics and Society 49, 1 (Spring): 1-30.

Kitschelt, Herbert, Kirk A. Hawkins, Juan P. Luna, Guillermo Rosas, and Elizabeth J. Zechmeister. 2010. Latin American Party Systems. New York: Cambridge University Press.

Lagos, Marta. 1997. Latin America's Smiling Mask. Journal of Democracy 8, 3: 125-38.

2001. Between Stability and Crisis in Latin America. Journal of Democracy 12, 1 : $137-45$.

Layton, Matthew L., and Amy E. Smith. 2015. Incorporating Marginal Citizens and Voters: The Conditional Electoral Effects of Targeted Social Assistance in Latin America. Comparative Political Studies 48, 7: 854-81. 
Leuven, Edwin, and Barbara Sianesi. 2003. PSMATCH2: Stata module to perform full Mahalanobis and propensity score matching, common support graphing, and covariate imbalance testing. Version 4.0.6, May 17, 2012.

Levy, Santiago. 2006. Progress Against Poverty: Sustaining Mexico's Progresa-Oportunidades Program. Washington, DC: Brookings Institution Press.

Licio, Elaine C., Lucio R. Rennó, and Henrique C. Castro. 2009. Bolsa Família e voto na eleição presidencial de 2006: em busca do elo perdido. Opinião Pública 15, 1: 3154.

Lindert, Kathy, Anja Linder, Jason Hobbs, and Bénédicte de la Brière. 2007. The Nuts and Bolts of Brazil's Bolsa Família Program: Implementing Conditional Cash Transfers in a Decentralized Context. Report 39853. Washington, DC: World Bank. http://documents.worldbank.org/curated/en/972261468231296002/pdf/398530SP1709.pdf

Linos, Elizabeth. 2013. Do Conditional Cash Transfer Programs Shift Votes? Evidence from the Honduran PRAF. Electoral Studies 32, 4: 864-74.

Linz, Juan J., and Alfred C. Stepan. 1996. Toward Consolidated Democracies. Journal of Democracy 7, 2: 14-33.

Magaloni, Beatriz, Alberto Díaz-Cayeros, and Federico Estévez. 2009. Welfare Benefits, Canvassing, and Campaign Handouts. In Consolidating Mexico's Democracy, ed. Jorge I. Domínguez, Chappell Lawson, and Alejandro Moreno. Baltimore: Johns Hopkins University Press. 229-45.

Mainwaring, Scott, and Aníbal Pérez-Liñán. 2013. Democracies and Dictatorships in Latin America: Emergence, Survival, and Fall. New York: Cambridge University Press.

Manacorda, Marco, Edward Miguel, and Andrea Vigorito. 2011. Government Transfers and Political Support. American Economic Journal: Applied Economics 3, 3: 1-28.

Marques, Rosa M., and Áquilas Mendes. 2006. O social no governo Lula: a construção de um novo populismo em tempos de aplicação de uma agenda neoliberal. Revista de Economia Politica 26, 1: 58-74.

2007. Servindo a dois senhores: as políticas sociais no governo Lula. Revista Katálysis 10, 1: 15-23.

Meneguello, Rachel. 2010. Algunos aspectos da lógica de coalizóes partidárias / Cidadãos e política: diagnóstico da adesão democrática, comportamento e valores. Textos para discussão CEPAL/IPEA no. 8. Brasília: Comissão Econômica para a América Latina e o Caribe/Instituto de Pesquisa Econômica Aplicada.

Morlino, Leonardo, and José R. Montero. 1995. Legitimacy and Democracy in Southern Europe. In The Politics of Democratic Consolidation: Southern Europe in Comparative Perspective, ed. Richard Gunther, P. N. Diamandouros, and Hans-Jürgen Puhle. Baltimore: Johns Hopkins University Press. 231-60.

Moura, Paulo G. M. de. 2007. Bolsa Família: projeto social ou marketing político? Revista Katálysis 10, 1: 115-22.

Nicolau, Jairo, and Vitor Peixoto. 2007. As bases municipais da votação de Lula em 2006. Rio de Janeiro: Instituto Nacional de Altos Estudos.

Norris, Pippa. 1999. Introduction: The Growth of Critical Citizens? In Critical Citizens: Global Support for Democratic Government, ed. Norris. New York: Oxford University Press. 1-27.

Peixoto, Vitor, and Lucio Rennó. 2011. Mobilidade social ascendente e voto: as eleiçôes presidenciais de 2010 no Brasil. Opiniäo Pública 17, 2: 304-32.

Penfold-Becerra, Michael. 2007. Clientelism and Social Funds: Evidence from Chávez's Misiones. Latin American Politics and Society 49, 4 (Winter): 63-84. 
Piven, Frances F., and Richard A. Cloward. 1971. Regulating the Poor: The Functions of Public Welfare. New York: Pantheon Books.

Powers, Nancy R. 2001. Grassroots Expectations of Democracy and Economy: Argentina in Comparative Perspective. Pittsburgh: University of Pittsburgh Press.

Rocha-Menocal, Alina. 2001. Do Old Habits Die Hard? A Statistical Exploration of the Politicisation of Progresa, Mexico's Latest Federal Poverty-Alleviation Programme, Under the Zedillo Administration. Journal of Latin American Studies 33, 3: 513-38.

Rothstein, Bo. 1998. Just Institutions Matter: The Moral and Political Logic of the Universal Welfare State. New York: Cambridge University Press.

Schady, Norbert R. 2000. The Political Economy of Expenditures by the Peruvian Social Fund (FONCODES), 1991-95. American Political Science Review 94, 2: 289-304.

Soares, Fábio V., Rafael P. Ribas, and Rafael G. Osório. 2010. Evaluating the Impact of Brazil's Bolsa Família: Cash Transfer Programs in Comparative Perspective. Latin American Research Review 45, 2: 173-90.

Soares, Gláucio A. D., and Sonia L. Terron. 2008. Dois Lulas: a geografia eleitoral da reeleição (explorando conceitos, métodos e técnicas de análise geoespacial). Opinião Pública 14, 2: 269-301.

Soss, Joe, Richard C. Fording, and Sanford F. Schram. 2011. Disciplining the Poor: Neoliberal Paternalism and the Persistent Power of Race. Chicago: University of Chicago Press.

Sugiyama, Natasha, and Wendy Hunter. 2013. Whither Clientelism? Good Governance and Brazil's Bolsa Família Program. Comparative Politics 46, 1: 43-62.

Wells, Jason M., and Jonathan Krieckhaus. 2006. Does National Context Influence Democratic Satisfaction? A Multi-Level Analysis. Political Research Quarterly 59, 4: 569-78.

Weyland, Kurt. 2012. Populism in the Age of Neoliberalism. In Populism in Latin America, 2nd ed., ed. Michael L. Conniff. Tuscaloosa: University of Alabama Press. 201-22.

Zucco, Cesar. 2008. The President's "New" Constituency: Lula and the Pragmatic Vote in Brazil's 2006 Presidential Elections. Journal of Latin American Studies 40, 1: 29-49.

- 2013. When Payouts Pay Off: Conditional Cash Transfers and Voting Behavior in Brazil, 2002-10. American Journal of Political Science 57, 4: 810-22.

Zucco, Cesar, and Timothy J. Power. 2013. Bolsa Família and the Shift in Lula's Electoral Base, 2002-2006: A Reply to Bohn. Latin American Research Review 48, 2: 3-24.

\section{SUPPORTING INFORMATION}

Additional supporting materials maybe found with the online version of this article at the publisher's website: Appendix: Supplemental Material and Analyses 